\title{
The Effect Of Character Education On Student Learning Outcomesat St. Yoseph Chatolic Junior High School In Medan
}

\author{
Rejeki Intan Anggreani Sagala \\ \{intansg1999@gmail.com \} \\ Postgraduate Program, Pelita Kebenaran School Of Theology
}

\begin{abstract}
Character education is very important to be applied in the field of education, especially in schools. To realize the good and noble characters in students, character education needs to be developed. The purpose of this study is; (1) to find out the effect of character education seen from the value of honesty on student learning outcomes of St. Yoseph Chatolic Junior High School, Medan; (2) to find out the effect of character education seen from the value of discipline on student learning outcomes of St. Yoseph Chatolic Medan junior high school students; (3) to find out the effect of character education seen from the value of independence on student learning outcomes of St. Yoseph Chatolic Medan junior high school students. The subjects of this study were eighth grade students of St. Yoseph Chatolic Medan junior high school. This study is quantitative descriptive research. The data collection techniques used in this study were questionnaires and teacher documentation.
\end{abstract}

Key Words:Character Education, Student Learning Outcomes

\section{Introduction}

Education is a very important thing and cannot be separated from the life of the nation and state, because education with good quality is one of benchmarks of the progress of a nation. Education with good quality will produce human resources with good quality as well and human resources with good quality are the main proponents in nation building. Suyadi (2012: 4) says that to build a nation with a complete identity, an education system that has holistic material is needed, and is supported by good management and implementation, and national education must be of quality and character. This is related to the character formation of students so that they are able to compete, have good morals, be ethical, polite and interact with the society.

The Government of Indonesia, through MONE since 2010, is committed to implementing character education for all levels of education, from elementary school to college. The emergence of the idea of character education programs in the world of education is understandable, because so far the process of education in Indonesia has apparently not succeeded in building human resources with good character. This is in line with Wahyu (2011: 140) saying that the condition of the nation's life is considered to be in crisis, if the world of formal education only educates the life of the people, without balanced cultivation of the values of human dignity, it has not contributed greatly to the realization of a just and prosperous society.Kesuma, et al. (2011: 5) say that "Character education is learning that leads 
to the strengthening and development of a child's behavior as a whole that is based on a certain value referred to by the school."

So character education is the process of giving guidance to students to become fully human with good characters in the dimensions of heart, mind, body, and feeling and intention, which lead to individual moral maturity. In other words, the character is interpreted as a good personal quality, in the sense of knowing goodness, willing to do good, and actually behaving well. While the purpose of character education is to improve the quality of the implementation and results of education in schools that lead to the achievement of the formation of character and noble character of students in an integrated, intact, and balanced manner in accordance with graduate competency standards. Through character education, students are expected to be able to independently improve and use their knowledge, study and internalize and personalize the values of character and noble character so that it manifests in daily behavior.

Character education is very important to be applied in schools because the application of character education will have a direct impact on the learning outcomes of students. According to Sudjana (in Wahyulion, 2013) learning outcomes are abilities possessed by students after receiving their learning experience. Students who respond to the application of character education are characterized by changes in actions or behavior towards a better direction. For example: (1) the application of disciplinary character education will change the behavior of students to be orderly and always comply with applicable regulations; (2) the application of character independence education will make students always actively study without being instructed and supervised, students will actively search for their own learning materials not only limited to what the teacher delivered. Just like previous studies conducted in California by Benninga (2003: 28) that schools that implement character education are academically excellent and more contributed to schools and their communities, schools that implement character education provide opportunities and encourage students to participate in voluntary activities such as cross-age guidance, fundraising for charity activities, community environmental cleaning programs, visits to nursing centers, and students in the school volunteering in their communities, as well as in hospitals. And character education with good quality in elementary schools correlates with higher scores on the academic grade point in California. Based on the description above, good character has a direct impact on student learning outcomes in the class. Of the 18 character values brought up by MONE through the curriculum research and development center (Ministry of National Education in 2010), the researcher selects three of them. The objectives of this study are; (1) to find out the effect of character education seen from the value of honesty on student learning outcomes of St. Yoseph Chatolic Junior High School, Medan; (2) to find out the effect of character education seen from the value of discipline on student learning outcomes of St. Yoseph Chatolic Medan junior high school students; (3) to find out the effect of character education seen from the value of independence on student learning outcomes of St. Yoseph Chatolic Medan junior high school students.

\section{Research Methodology}

The type of this research is descriptive research and the type of approach used in this study is quantitative research. According to Arikunto (2010:27) in quantitative research it is required to use numbers, starting from data collection, interpretation of the data and the appearance of the results. The subjects in this study were eighth grade students of St. Yoseph 
Medan Catholic Junior High School which numbered 90 students in the even semester of the 2018/2019 academic year. The reason the researchers conducted research at the St. Yoseph Medan Catholic Junior High School was based on the results of observations and interviews with several teachers in the school that character education was implemented. And it's also seen from the learning device used by the teacher who taught at the school that in the design of the learning device used the values of character education were visible. The technique of collecting data in this study was by distributing questionnaires to students who were the subjects in this study. Questionnaires are used to collect data about honest, disciplined, and independent characters. The second technique of data collection is by documenting the homeroom teacher at St. Joseph Catholic Junior High School in Medan. According to Sugiyono (2013: 240) documentation is a record of past events. Documentation can be in the form of writing, drawing, or monumental works from someone. Documentation in the form of writing is such as diaries, history of life (life histories), stories, biographies, regulations, policies. And documentation in this study is used to collect data on student learning outcomes.

\section{Result and Discussion}

\subsection{Description of Character Education of Honesty Value towards Learning Outcomes}

Character education of honesty instilled in students will make students have the character of honesty in themselves. Honest means being upright, not lying in words and in deeds, not cheating (in games, examinations), and always following applicable regulations. Someone who has an honest attitude makes the student well accepted in the school and community environment. Students who have honest character will have an impact on student learning outcomes. The character education of honesty value that has been applied to eighth grade students of St. Yoseph Medan Catholic Junior High School results in students having honest character values. The results of the honesty questionnaire from the research conducted on the eighth grade students of St. Yoseph Medan Catholic Junior High School can be seen from the following diagram.

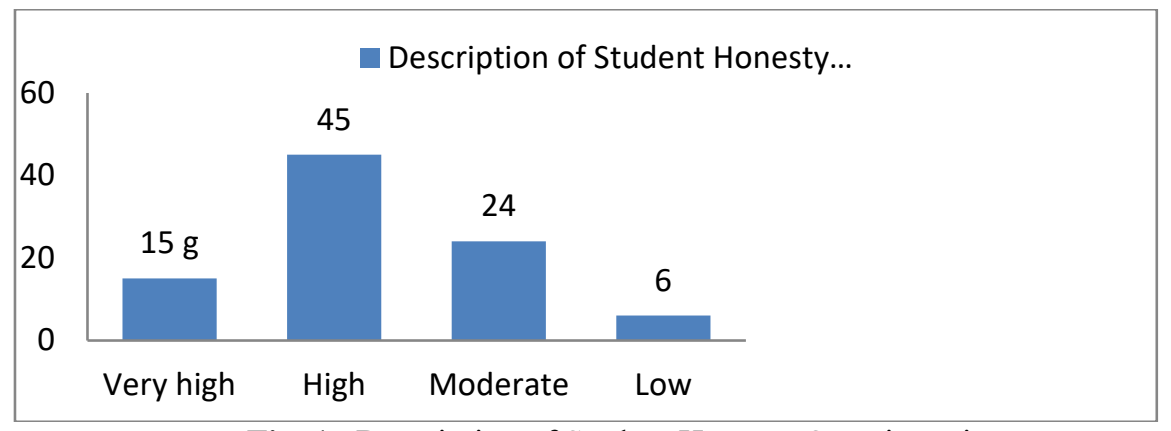

Fig. 1. Description of Student Honesty Questionnaire

From Figure 1. It shows that character education seen from the honesty value of eighth grade students of St. Joseph Catholic Junior High School in Medan was obtained as many as 15 students (16. 7\%) had very high honesty, 2) as many as 45 students (50\%) had high, 3 ) 24 students $(26.7 \%)$ have moderate honesty, 4$) 6(6.6 \%)$ have low honesty. The highest score was 
52 and the lowest one was 24 with an average of 43.5. From the description above it can be concluded that most of the eighth grade students of St. Yoseph Medan Catholic Junior High School have high honesty. Results of regression analysis were used to see the effect of honesty on student learning outcomes in eighth grade students of St. Joseph Catholic Junior High School in Medan, and a significant level of 0, 329 was obtained which means that honesty influences the learning outcomes of eighth grade students of St. Joseph Catholic Junior High School Medan. This is supported by previous research conducted by Hanif Ardiansyah and Andrie Prasetyo (2013) stating that learning outcomes of discipline students are not much different from honest student learning outcomes

\subsection{Description of Character Education of Discipline Value towards Learning Outcomes}

Discipline is an attitude that every student needs to have. With discipline, it is expected that all structured activities can be carried out properly and get good results. Even in learning, students need to have discipline to achieve successful learning, both at home and at school. If there is a good discipline in students, then perseverance and obedience will continue to increase so that the learning outcomes will also increase. Student discipline includes discipline in leaving for school, discipline in following learning in class, discipline in doing assignments, discipline in learning at home and discipline in obeying school rules. Character education of discipline value that has been applied to eighth grade students of St. Yoseph Medan Catholic Junior High School results in students having disciplinary character values. The results of the questionnaire from the research conducted on the eighth grade students of St. Yoseph Medan Catholic Junior High School can be seen from the following diagram.

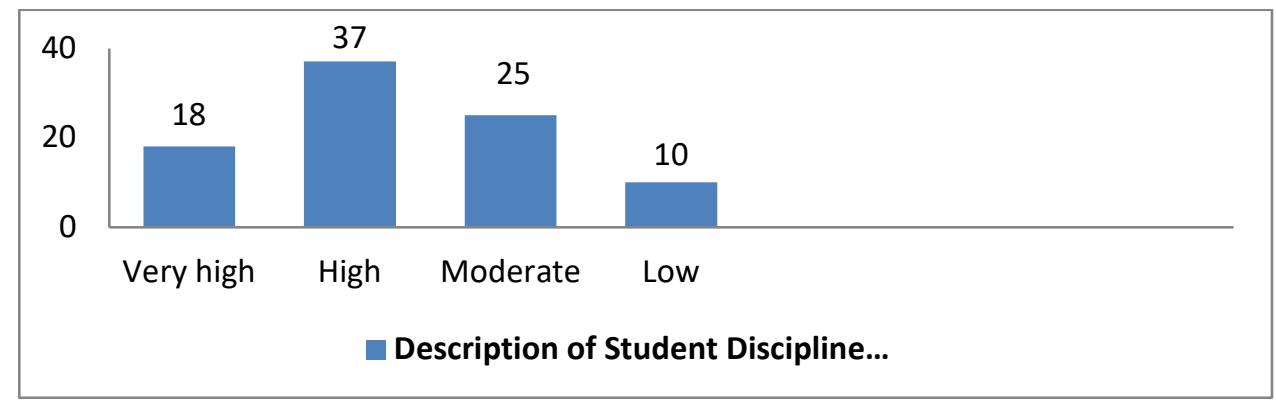

Fig. 2. Description of Student Discipline

From Figure 2. It shows that character education seen from the value of disciplinary eighth grade students of St. Joseph Catholic Middle School in Medan as many as 18 students (20\%) have very high discipline, 2) as many as 37 students (41\%) have high, 3) as many 25 students $(27.7 \%)$ are in moderate discipline, 4$)$ as many as $10(11.1 \%)$ have low discipline. The highest score was 53 and the lowest one was 34 with an average of 44.3. From the abovedescription it can be concluded that most of the eighth grade students of the Catholic Junior High School of St. Joseph Medan have high and moderate honesty. The results of regression analysis were used to see the effect of discipline on student learning outcomes in eighth grade of St. Joseph Catholic Middle School in Medan, and a significant level of 0, 273 was obatined which means that disciplinary attitudes influence the learning outcomes of eighth grade students of St. Joseph Catholic Junior High School Medan. This research is supported by previous research conducted by Stanley Ehiane (2014), a student from Lagos 
State Polytechnic, Nigeria under the title "Disciple and Academic Performance (A Study of Selected Secondary schools in Laos, Nigeria)." The study used a cross-sectional survey design where the questionnaire was the main instrument of data collection in addition to interviews and documentation. Simple percentages and Chi-square statistical methods are used to analyze data. The results of the study indicate that school discipline and rules affect the academic achievement of students at school. And this is also in line with the research conducted by Philomena Mukami Njoroge and Ann Nduku Nyabuto (2014), students from Mount Kenya University, School of Education entitled "Discipline as a Factor in Academic Performance in Kenya". The results showed that discipline is the main factor that influences student academic achievement both inside and outside the school.

\subsection{Description of Character Education of Independence Value towards Learning Outcomes}

Independence is an attitude and behavior of individual self-regulating and not depending on other people to complete all tasks in their lives, including learning. Independence in learning will be realized if students actively control everything that is done, evaluate and then plan something more in learning that has been passed and also want to be active in the learning process. The character education of the independence value that has been applied to the eighth grade students of St. Yoseph Medan Catholic Junior High School has resulted in students having a high spirit of independence. Based on the data obtained from questionnaires by using 4 answer choices, the scores given are as follows: 1. For statements that lead positively are given a score of 4 , whereas negative leads are given a score of 1 . After being transformed, the acquisition of scores resulting from the spread questionnaires are interpreted into 4 (four) categories. The results of the independence questionnaire from the research conducted on the eighth grade students of the Catholic School of St. Yoseph Medan can be seen from the following diagram.

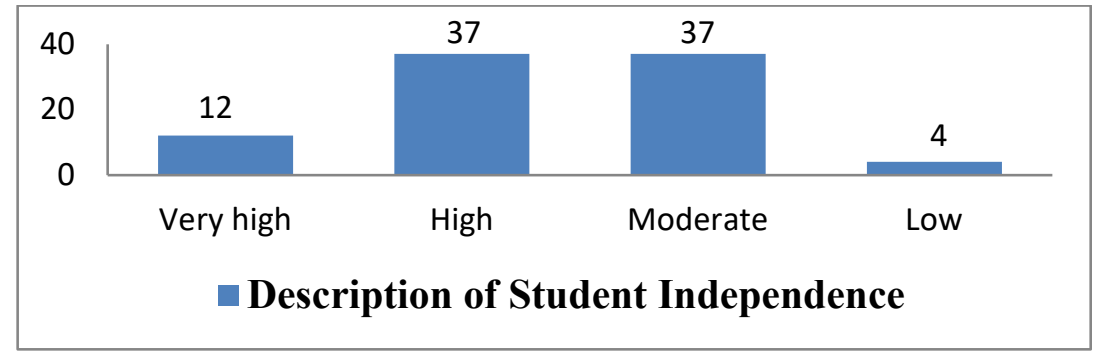

Fig . 3. Description of Student Independence

Based on figure 3. it can be described as follows: 1. A total of 13 or $13.3 \%$ of students obtained very high category scores. 2. A total of 37 or $41.1 \%$ of students obtained questionnaires with a high category. 3. A total of 37 or $41.1 \%$ of students obtainedquestionnaire scores in the medium category. 4 . As many as 4 or $4.5 \%$ of students obtain a low category. The highest score was 56 and the lowest one was 32 with an average of 42.25. The results of regression analysis were used to see the effect of independence on student learning outcomes in eighth grade of St. Joseph Catholic Junior High School Medan, and a significant level of 0.295 was obtained which means that the attitude of independence affects the learning outcomes of eighth grade students of Saint Joseph Catholic Junior High School Medan. The result of this study is supported by previous research which concluded that 
learning independence has a positive effect on learning outcomes so this can be considered by teachers to grow affective with real actions through extracurricular programs and teaching and learning activities in the classroom with effective learning strategies or models.

\section{Conclusion}

Based on the results and discussion, some conclusions were obtained, namely: (1) The attitude of honesty has an effect on the learning outcomes of eighth grade Catholic Students of Saint Joseph Medan with an average honesty score of 43.5 students; (2) most of the eighth grade students of Saint Yoseph Medan Catholic Junior High School have high and moderate discipline with an average discipline score of 44.3. (3) the attitude of independence influences the learning outcomes of eighth grade students of St. Joseph Catholic Junior High School in Medan with an average score of students' independence of 42.25. Overall, character education seen from the values of honesty, discipline, and independence influences student learning outcomes.

\section{Suggestion}

After conducting this study, the suggestions are (1) the Education / School Institutions should always implement character education of honesty, discipline, and independence in order to improve student learning outcomes. (2) students should maintain the character of honesty, discipline, and independence both in the school, family, and community environment. (3) Parents of students should pay attention to student learning activities both at home and outside the home and familiarize students to conduct independent learning activities, so that children have learning independence that can improve their learning outcomes.

\section{References}

[1] Ardiansyah, Hanif Dan Prasetyo, Andrie. 2013. Pengaruh Konsep Diri Dan Kedisiplinan Terhadap Prestasi Belajar Siswa Jurusan Tehnik Audio Video Di SMK 3 Yogyakarta. No. 2

[2] Benninga, S, J. 2013, The Relationship Of Character Education Implementation And Academic Achievement In Elementary Schools. Journal Of Research In Character Education, 1(1), 2003, Pp. 19-32. Issn 1543-1223.

[3] Ehiena, O. S. 2014. Disciple And Academic Performance (A Study Of Selected Secondary schools In Lagos, Nigeria). International Journal Of Academic Research In Progressive Education And Development. . Vol.3 No. 1.

[4] Kesuma. D, Dkk . 2011, Pendidkikan Karakter Kajian Teori Dan Praktik Di Sekolah. Penerbit Pt Remaja Rosdakarya. Bandung

[5] Njoroge. P, \& Nyabuto.N,. 2014. Discipline As A Factor In Academic Performance In Kenya. Journal Of Educational And Social Research. Vol.4 No.1

[6] Sugiono, 2013, Metode Penelitian Kuantitatif, Kualitatif Dan R\&D. Alfabeta. Bandung

[7] Suyadi, 2012. Srategi Pembelajaran Karakter . Penerbit Pt Remaja Rosdakarya. Bandung

[8] Wahyu, 2011, Masalah Dan Usaha Membangun Karakter Bangsa. Journal.Unnes. Komunitas. ISSN 2086-5465

[9] Wahyuliono. T, 2013, Pengaruh Pendidikan Karakter Terhadap Hasil Belajar Siswa Kelas Xi Pada Mata Pelajaran Produktif Teknik Mesin Di SMKN 1 Trenggalek. Jurnal Teknik Mesin, Tahun 21, No. 1, April 201. 